\title{
The Effectiveness Of Credit Derivatives On Bank Holding Company Portfolio Management
}

Vernie Alexander-Andrew, (E-mail: avernie@ nova.edu), Nova Southeastern University

\begin{abstract}
Since their introduction in 1991, the global credit derivatives market (excluding asset swaps) has grown, exceeding previous expectations for 2003, with an estimated market of $\$ 3,548$ billion or $\$ 3.5$ trillion. Growth is expected to reach $\$ 8.2$ trillion by 2006 (BBA 2004). At the time of entry to the market in the early 1990's, it was also expected that the largest potential customers would be commercial banks that are the largest holders of risky debts. In 2005 as in previous years, banks, securities houses and insurance companies still constitute the majority of market participants while hedge funds, which emerged as players on the buy side of the market in the last report, have this year also become major players on the sell side, and are expected to have a greater share of the market than securities houses by 2006 (BBA, 2002) While market risk allows opportunities for both profits and losses, credit risks only result in losses, and the objective of this research is to examine the effectiveness of credit derivatives as a risk management tool in improving the performance of portfolios for Bank Holding Companies (BHC's).
\end{abstract}

\section{INTRODUCTION}

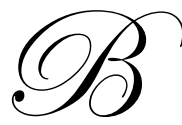

anks are among the leading repositories of public's savings, particularly individuals and families, and the loss of these funds due to bank failure would be catastrophic to many individuals and families. A BHC is a company that owns and/or controls one or more U.S. banks, or one that owns, or has controlling interest in, one or more banks. A BHC can own another BHC, which in turn owns or controls a bank.

The primary objective of this research is to examine the effectiveness of credit derivatives as a risk management tool in improving the performance of bank portfolios for BHC's.

This research contains five chapters. The first chapter introduces banking and credit risk, a technical discussion of credit derivatives and the history and current status of credit derivatives in banking. Chapter 2 is a Review of the Literature of previous research on this and related topics. In Chapter 3, Research Methodology is presented, and Hypotheses are developed. Chapter 4 presents an empirical analysis of the data. Chapter 5 provides Summary and Conclusions.

\section{Chapter 1}

Although non-financial corporate debt (bond issues and privately issued debt) has become more common in the past 10-20 years, bank loans are still the prime source of business finance, especially for Small and Medium size Enterprises (SMEs). As a consequence, banks' ex-ante assessment of the riskiness of loan applicants, the resulting decision to grant credit (or not), at some risk-adjusted interest rate, and the way in which monitoring granted loans takes place, are of great importance for most businesses (Jacobson, Lindé \& Roszbach, 2006). This is because unlike market risk which provides either profit or loss opportunities, credit risk results in losses only. 
Assessing borrower risk is generally considered one of the banking industry's core activities. Banks' role as intermediary is commonly explained by their supposedly superior ability to collect and assess information with respect to borrower risk. Research has been extensive in this area, since Diamond (1984) formalized the concept of a delegated monitor and Fama (1985) proposed that banks were special relative to alternative lenders. Lummer \& McConnel (1989) and Mester, Nakamura \& Renault (2004) for example, describe the details of bank monitoring based on bank access to borrowers' transaction accounts - that may make banks superior monitors (Jacobson et al.).

The risk of borrower default - on interest and/or principal - carries the potential of wiping out enough of a bank's capital to force it into bankruptcy. Default occurs when a borrower cannot fulfill key financial obligations, such as making interest payments to bond holders, or repaying bank loans. In the event of default, lenders, bond holders or banks suffer a loss because they will not receive all the payments promised to them (Neal, 1996). Additionally, banks tend to concentrate their loans geographically or in particular industries, which limits their ability to diversify credit risks across borrowers. Banks whose lending may be concentrated may want to diversify these risks.

Credit risk is one of the oldest and most important forms of risk faced by banks as financial intermediaries, and is the must fundamental element in lending. Therefore, managing credit risk through selection, monitoring and creating a diversified loan portfolio has always been one of the main challenges in running a bank. Credit risk is the probability that a borrower will default on a commitment to repay debt or bank loans. The level of banks holding of owners' capital relative to the aggregate value of their assets means that even a small percentage of loans going into the non-performing category is enough to threaten the survival of the bank. (Rose \& Hudgins, 2005).

One way to reduce credit risk is to sell loans. Most bank loans however, are not easily marketable. Furthermore, selling loans can impair the relationship with borrowers, which is important in the banking business (Park, 1998). A bank may hold a portfolio of loans that may not be liquid. For this and other reasons, it may not be prudent to sell the loans however, with credit derivatives, the bank is able to re-shape their loan portfolio, thereby managing conflicting objectives (Dong, 2005).

Since the 1980s a number of new risk sharing markets and financial instruments have become available, which make credit risk more manageable. More recently, credit derivatives such as credit swaps, credit options, and credit-linked notes have gained importance as hedge instruments to manage risk in situations where the diversity of loan types and credit risks make it difficult to securitize loans or sell them individually (Broll, Pausch \& Weltz, 2002).

Credit derivatives strip default risk from debt instruments and isolate credit risk from other forms of risk (such as market or operational risk) of a particular asset or credit, and transfers that risk from one party to another (Brandon \& Fernandez, 2005). They are contracts that transfer credit risk from a holder (buyer) of risky bonds or loans (reference asset) to a third party (seller). By entering into such a contract, the buyer reduces or eliminates credit risk without selling the reference asset, and the seller expects to make a profit from assuming risk (Park, 1998).

Credit swaps and total return swaps are the two most popular types of credit derivatives. In a credit swap, the buyer makes periodic payments (quarterly or annual in most cases) of a fixed percentage of the underlying asset (reference asset) to the seller, over the life of the swap, and the seller promises a payment, contingent upon publicly observable credit events such as bankruptcy, delinquency, or a credit rating downgrade. In general, a credit event must be one that is publicly observable and materially affects the value of the reference asset. The contingent payment may be a predetermined amount or the decrease in the market value of the reference asset caused by credit events. In essence, this arrangement is insurance against default. Periodic payments may be regarded as insurance premiums, and the contingency payment as an insurance payout (Park, 1998).

In a total return swap, the buyer and the seller periodically exchange payments. The buyer pays the total return on the underlying asset (including interest payments, amortization of the principle and appreciation of the market value), and the seller pays either a floating or fixed rate (depending on preference), plus any depreciation of the reference asset. The floating interest rate is usually determined based on the London Inter-Bank Offering Rate (LIBOR). Purchasing a total return swap, therefore, is equivalent to selling the reference asset and investing the 
proceeds in default-free bonds. Provided that the contract is honored, the buyer is thus protected against both default and interest rate risks during the life of the swap, which is typically shorter than the maturity of the reference asset. Furthermore, total return swaps provide a more complete protection against default risk than credit swaps. An increase in the default probability can decrease the value of the reference asset without triggering a credit event specified by a credit swap. In this case, the buyer of the credit swap would not be compensated for the depreciation on the reference asset (Park, 1998).

Credit derivatives can be used to reduce the portfolio's exposure to certain obligators or to diversify the portfolio by synthetically accepting credit risk from industries or geographic regions that were underweighted in the portfolio. Therefore credit derivatives can alter the risk and return characteristics of a portfolio and enable portfolio managers to achieve an "efficient portfolio," (Dong, 2005).

The use of credit derivatives by banks is therefore motivated by the desire to improve portfolio diversification (synthetically) and to improve the management of credit portfolio's (Das, Fong \& Geng, 2001 and Morrison, 2005).

\section{Chapter 2}

This chapter introduces prior research into credit derivatives use in the financial services industry.

Earlier literature on credit derivatives is rich and has mainly focused on the problem of measuring, as accurately as possible, the credit risk of bank portfolios' (Duffie \& Pan, 1997), and to analyze how these risks can best be reduced (Jackson, Maude \& Perruadin, 1997).

Credit derivatives have some distinctive features that make the pricing and the hedging of those products more difficult. The value of a credit swap depends on the default probability and unlike macroeconomic variables such as the interest rate, the default probability is idiosyncratic. That is, it varies across borrowers and so standard methodologies for pricing may not be applicable across all cases. There is also another problem when the buyers of credit derivatives are better informed about their borrowers than the sellers. If the sellers estimate default probabilities and price credit derivatives based on commonly observable characteristics of the borrowers, the buyers, who have more detailed information about the borrowers, will know whether credit derivatives on their assets are under priced or overpriced.

The guarantor of a bank loan faces another difficulty. Normally banks monitor borrowers using their private information gathered through lending relationships so that borrowers do not become riskier after loans are made. Once default risk is transferred however, banks do not have incentives to monitor borrowers. The default probability is then likely to increase after a credit derivative contract is written on the loan. In this case, the seller would suffer losses even if it accurately estimated the default probability at the time of the deal (Park, 1998).

Asher (1998) referred to credit derivatives as a red-hot growth area, and an innovative product that would need to overcome major difficulties, mainly pricing and counterparty risk, before it is widely applied.

Neal (1996) considers that while credit derivatives provide a valuable tool for managing risks, they can also expose the user to new financial risks and regulatory costs, such as operational risk, counterparty risk, liquidity risk and legal risk. His conclusion was that there are still unresolved uncertainties associated with regulatory status, legal status and adequacy of internal control procedure.

Herring (1999) looked at credit derivatives and financial instability and cites inept credit risk management as the reason for bank failures. Recent advances in modeling credit risk can bring much greater discipline to the pricing of credit risk and should promote diversification by penalizing concentrations of credit risk with greater allocations of economic capital. Over the past decade most major banks have invested heavily in the development of credit risk models that will enable them to measure and manage credit risk more effectively. The goal is to depict the probability 
density function of losses from credit risk for the bank as a whole and for each credit facility, product, customer, and line of business, in order to evaluate the capital necessary to support the exposures.

Broll, Pasuch \& Weltez (2002) used the industrial organization approach to the microeconomics of banking to study the implications of credit risks and credit derivatives with and without basic risk for optimal bank behavior in the loan and deposit markets under risk aversion, when credit derivatives to hedge credit risk are available. They concluded that there is still a separation of product decisions and risk management.

Duffee \& Zhou (2001) analyze whether the introduction of a credit derivatives market may not be desirable because it can cause other markets for loan risk sharing to break down. A bank can use credit-default swaps to temporarily transfer credit risks of their loans, thereby reducing the likelihood that defaulting loans trigger the bank's financial distress. They conclude that theory alone cannot determine whether the market for credit derivatives will help banks better manage their loan credit risks.

Broll, Schweimayer \& Welzel (2004) analyze the implications of credit risk, credit derivatives and macro derivatives on the optimal behavior of a single large bank under risk aversion to derive separation results and hedge rules.

Bank supervisors increasingly rely on input from internal risk measurement models when calculating capital adequacy requirements. The problem of risk assessment is important as it is a key tool for controlling systematic risk. Hedge instruments have been seen largely as a route to control firm risk and Instefjord (2005) analyzes risk taking behavior in the presence of hedge opportunities and whether access to such hedge instruments also encourages risk taking in the underlying credit market, thereby offsetting the potential risk reducing benefits of hedging. The findings are that access to hedge instruments is an important determinant of total risk exposure for banks and does not necessarily reduce risk exposure. As a result, a regulator should be concerned about the competitive nature of the underlying credit markets when assessing whether credit derivatives pose a destabilizing threat to the banking sector.

Since credit derivatives were introduced, there have been several studies. Recent studies examined the effectiveness of credit derivatives on bank portfolio management (Dong, 2005). However, while empirical analysis has been conducted regarding bank portfolios at the individual commercial bank level (Broll et al.), and for community banks (Robicheaux, 2005), none has empirically examined the effects of credit derivatives on BHC's. This study bridges the gap by analyzing and empirically testing the relationship between credit derivatives and the performance of BHC's

\section{Chapter 3}

This chapter introduces the base theory, research questions and the research methodology for approaching the research questions. It begins by defining the theory, followed by the definition and measurement of the performance of bank portfolios. The primary and secondary research questions are discussed, followed by an explanation of the selection of variables selected, the main model, development of hypothesis and finally, the data source and its reliability.

This study is based on Modern Portfolio Theory (MPT), and the application of The Capital Asset Pricing Model (CAPM).

CAPM was developed around a hypothetical world where investors are risk-averse individuals who maximize the expected utility of their wealth; where investors are price takers and have homogeneous expectations about asset returns that have a joint normal distribution; where there exists a risk free asset such that investors may borrow or lend unlimited amounts at a risk-free rate; where the quantities of assets are fixed, marketable and perfectly divisible; where asset markets are frictionless (the borrowing rate equals the lending rate) and information is costless and simultaneously available to all investors; and where there are no market imperfections such as taxes, regulations or restrictions on short selling (Copeland, Weston \& Shastri 2005). These assumptions are not representative of the market in actuality, however allows the development of the CAPM. Because it provides a quantifiable measure of 
risk for individual assets, CAPM is an extremely useful tool for valuing risky assets, however since it is based on historical data, it is more appropriate for relatively stable conditions.

We can apply CAPM to BHC bank portfolio's as we analyze whether or not the use of credit derivatives by BHC's reduce risk (standard deviation), or improve performance (risk adjusted rate of return).

MPT proposes expected (mean) return, $\mathrm{E}$, and variance of return, $\mathrm{v}$, of the portfolio as a whole, as criteria for portfolio selection and to form possible hypothesis about actual behavior. In this study, we seek to determine whether or not diversification, through the use of credit derivatives does impact BHC portfolio performance. Portfolio performance will be analyzed in terms of Risk (standard deviation), and Performance (Risk Adjusted Rate of Return).

Discussed above, one CAPM's assumptions, the Expected Value rule states that investors are risk-averse individuals who maximize the expected utility of their wealth. As developed in CAPM theory, banks, like other businesses operate with the objective to maximize shareholder wealth at the lowest acceptable level of risk. Therefore, profitability or return maximization and risk minimization are two important dimensions of performance.

A BHC bank portfolio consists of assets such as BHC deposits and loans; liabilities such as customer or other bank deposits; equity; and off-balance-sheet activities which include derivatives. A loan portfolio however, specifically refers to different types of bank assets: commercial loans and consumer loans, to name a few. At the BHC level, a portfolio consists of multiple bank holdings. This study looks at the bank portfolio overall.

Bank portfolio performance can be evaluated by return and risk. A number of financial ratios can be used to make an assessment. Portfolio return can be assessed using the commonly used profitability ratio - Return on Asset (ROA). ROA is a measure of managerial efficiency, and how successful management has been in converting assets into net earnings. It is defined as the ratio of Net Income After Taxes to Total Assets. To determine the effects of the use of credit derivatives on BHC portfolios, we can define risk as the change in ROA, or the risk adjusted return of the portfolio. This is calculated as the ratio between ROA and the standard deviation of ROA, as expressed in the formula:

$\mathrm{p}=\mathrm{ROA} / \sigma$

where: $\mathrm{p}=$ performance, $\mathrm{ROA}=$ Return on Asset and $\sigma=$ Standard Deviation of ROA

We would expect this relationship to hold: A lower standard deviation, signifying lower risk in the portfolio return, would either be associated with, or the result of, credit derivative use.

Our data set includes ROA for the first quarter of 1987 to the fourth quarter of 2006, obtained from The Uniform Performance Banking Report. Calculating standard deviation $(\sigma)$ poses a challenge, and this study will estimate $\sigma$ by computing the standard deviation of ROA for the past 29 quarters (including the current quarter). This is a feasible solution that has been used by many empirical studies. Dong (2005) used 29 quarters of past ROA to compute the standard deviation in his study of large commercial banks, to compute the standard deviation of ROA. Charest (1978) used three methods to compute beta. Two of his methods differed in the data sets. Method one used 61 months past data to include time t, while Method two used 30 months data on either side of $t$. This method is theoretically supported because beta and standard deviation are positively correlated as shown in the formula:

Beta $=\sigma$ stock * return stock market $/ \sigma$ market

where: $B$ eta $=$ the beta of the stock and the market portfolio, $\sigma$ stock $=$ the standard deviation of the stock, $\sigma$ market $=$ the standard deviation of the market portfolio and $\mathrm{r}$ stock market $=$ the correlation between the stock and the market portfolio.

The standard deviation for ROA has to be calculated. In computing the standard deviation of ROA for the first quarter of 1995, we will use the 28 preceding quarters, from the first quarter 1987 to the fourth quarter of 1993. Since credit derivative use exploded in the 1990's, and it was in 1995 that BHC's and other financial institutions were required to provide data on their credit derivative use, our analysis of credit derivative use covers the period from the 
first quarter of 1995 to the first quarter of 2006 . We have not lost essential data in using this method to compute the standard deviation as there was neither credit derivative use nor credit derivative regulatory reporting requirement prior to this time. Our data set consists of 41 quarters, which is still a robust data set. The sample consists of 14 of the top 50 BHC's; $28 \%$ of the population.

We obtain the list of the top BHC's from the National Information Center and generate two samples: BHC's that use derivatives and BHC's that do not use derivatives. For each sample, we compute and compare summary statistics, run regression analysis and perform T-test's. The variables that we will use in our analysis are defined as follows:

TAG Growth of Total Assets; EQ Equity Capital Ratio (Equity Capital divided by Total Assets); TL Total Loan/Leases to Assets Ratio (Total Loans and Leases divided by Total Assets); TD Total Derivatives to Assets Ratio (Total Derivatives divided by Total Assets); NCO Net Charge-Offs Ratio (Net Charge Offs divided by Total Loans and Leases); CDT Credit Derivatives to Assets Ratio (Total Credit Derivatives divided by Total Assets); CDBA Credit Derivatives, as Beneficiary to Assets Ratio (Total Credit Derivatives as Beneficiary divided by Total Assets); CDGA Credit Derivatives, as Guarantor to Assets Ratio (Total Credit Derivatives as Guarantor divided by Total Assets); ROA Return on Assets (Net Income divided by Total Assets); RAR Risk Adjusted Rate of Return (Return on Asset divided by standard deviation of ROA).

Since credit derivatives were introduced, there have been several studies. None has empirically examined the effects of credit derivatives on Bank Holding Companies. This study will fill the gap by empirically testing the relationship between credit derivatives and the performance of Bank Holding Companies. The primary objective of this research is to examine the effectiveness of credit derivatives on the performance of bank portfolios for BHC's. The primary research question is "Does the usage of credit derivatives improve the performance of bank portfolio's for BHC's?"

Three secondary research questions have been developed, to better answer the primary research question.

Will buying and selling credit derivatives affect the standard deviation (the risk) of BHC bank portfolio returns?

Banks generally buy credit derivatives to hedge against credit risk and to reduce the overall risk of bank portfolios. As a result, one would expect an inverse relationship between the amount of credit derivatives purchased and the risk in a bank portfolio.

On the other hand, banks also sell credit derivatives, and one would expect a direct relationship between the sale of credit derivatives and the risk in a bank portfolio. This could be particularly evident in an economic downturn, or when the bank's business is industry concentrated.

(2) Will buying and selling credit derivatives affect the return on BHC bank portfolios?

(3) Does buying credit derivatives lead to more bank loan defaults? This question is one of moral hazard.

These three research questions help answer the primary question, as we seek to learn if buying credit derivatives reduce risk in bank portfolio's; if selling credit derivatives increase the return on bank portfolio's; and if buying credit derivatives increase the risk of loan default because lower quality loans are granted. The answers show whether the use of credit derivatives increase or decrease risk for BHC's. We seek to test the following hypotheses: returns?

Will buying and selling credit derivatives affect the standard deviation (the risk) of BHC bank portfolio

H1: There is a relationship between buying credit derivatives and BHC Risk Adjusted Rate of Return.

H2: There is a relationship between selling credit derivatives and BHC Risk Adjusted Rate of Return. Will buying and selling credit derivatives affect the return on BHC portfolio? 
H3: There is a relationship between buying credit derivatives and BHC ROA.

H4: There is a relationship between selling credit derivatives and BHC ROA.

Will buying credit derivatives lead to greater loan defaults?

H5: There is a relationship between buying credit derivatives and BHC Net Charge Off To Loans Ratio.

\section{Chapter 4}

This chapter presents an empirical analysis of the data.

Data was collected on 14 BHC's covering the period 1994 to 2005 (41 total quarters). A dummy variable was created to separate those BHC's that did use Credit Derivatives from those that did not use Credit Derivatives. We analyzed summary statistics which show the following:

Net Charge Offs to Loans: The average Net Charge Offs To Loans was 0.011261 for those BHC's that did not use Credit Derivatives, while it was 0.024226 for those BHC's that did use derivatives.

Credit Derivatives To Assets Ratio: The average Credit Derivatives to Assets Ratio was 0.000171 for those that did not use credit derivatives and 0.119457 for those that did use credit derivatives.

Total Loans \& Leases to Assets: The average Total Loans \& Leases to Assets was 0.424638 for those that did not use credit derivatives and 0.603166 for those that did use credit derivatives.

Equity To Assets Ratio: The average Equity To Assets Ratio was 0.088173 for those that did not use credit derivatives and 0.086388 for those that did use credit derivatives.

Next, we analyzed the relationships between the two dependent variables: Rate of Return (Performance), and Risk Adjusted Rate of Return (Risk), and between each of the Independent Variables: Equity To Assets Ratio, Total Derivatives To Assets Ratio, Credit Derivatives To Asset Ratio, Growth Of Assets Quarter over Quarter, Total Loans $\&$ Leases To Assets Ratio, and Net Charge Offs To Loans. We also analyze the correlations between the Independent Variables.

The results of the correlation report show that:

ROA: There was no significant relationship between ROA and Equity To Assets Ratio. Significant at the $1 \%$ confidence level, there was a positive relationship between Total Loans \& Leases To Asset; Net Charge Offs To Loans; and Growth Of Assets Quarter Over Quarter. There was a negative relationship between Total Derivatives to Assets; Guarantor Credit Derivatives To Assets; Beneficiary Credit Derivatives To Assets; and Credit Derivatives To Assets.

Risk Adjusted Return on Asset:_ Significant at the $1 \%$ confidence level, there was a positive relationship between Risk Adjusted Return On Asset and: Growth Of Assets Quarter Over Quarter; Net Charge Offs To Loans and Total Loans \& Leases to Assets. There were negative relationships between Risk Adjusted Return On Asset and: Total Derivatives To Assets; Equity To Assets Ratio; Credit Derivatives To Asset Ratio; Guarantor Credit Derivative To Assets and Beneficiary Credit Derivatives to Assets.

\section{Chapter 5}


This chapter presents the conclusion and findings to the research question.

For BHC's that used credit derivatives (both as guarantor and beneficiary), the Risk Adjusted Return decreased by 0.168 when Total Derivatives increased by 1 . When BHC's that use credit derivatives are separately analyzed, Risk Adjusted Return increased by 0.274 when the BHC was the beneficiary, compared to decreasing by 0.270 when the BHC is acting in a guarantor capacity (Table 1). This result supports both $\mathrm{H} 1$ and $\mathrm{H} 2$, and our findings is that there is a relationship between buying credit derivatives and selling credit derivatives and BHC portfolio risk, when BHC's engaged in this risk management strategy. Our findings with respect to our Secondary question no. 1 are that BHC's credit derivative use does affect portfolio risk.

Table 1: Regression Analysis Risk Adjusted Return Against Independent Variables

\begin{tabular}{|c|c|c|c|c|c|c|}
\hline \multirow[t]{2}{*}{ Model } & & \multicolumn{2}{|c|}{ Unstandardized Coefficients } & \multirow{2}{*}{$\begin{array}{c}\begin{array}{c}\text { Standardized } \\
\text { Coefficients }\end{array} \\
\text { Beta }\end{array}$} & \multirow[b]{2}{*}{$\mathbf{t}$} & \multirow[b]{2}{*}{ Sig. } \\
\hline & & $\mathbf{B}$ & Std. Error & & & \\
\hline 1 & $\begin{array}{c}\text { (Constant) } \\
\text { TL } \\
\text { NCO } \\
\text { TD } \\
\text { CDGA } \\
\text { TAG } \\
\text { CDBA } \\
\text { EQ }\end{array}$ & $\begin{array}{c}6.947 \\
5.009 \\
16.503 \\
-.075 \\
-12.005 \\
.038 \\
11.026 \\
-29.183\end{array}$ & $\begin{array}{c}1.692 \\
1.555 \\
5.712 \\
.043 \\
13.844 \\
.033 \\
11.820 \\
15.534\end{array}$ & $\begin{array}{c}.183 \\
.155 \\
-.168 \\
-.270 \\
.066 \\
.274 \\
-.116\end{array}$ & $\begin{array}{c}4.107 \\
3.220 \\
2.889 \\
-1.755 \\
-.867 \\
1.129 \\
.933 \\
-1.879\end{array}$ & $\begin{array}{l}.00 \\
.0001 \\
.004 \\
.080 \\
.387 \\
.260 \\
.352 \\
.061\end{array}$ \\
\hline
\end{tabular}

a Dependent Variable: RAR

For BHC's that used credit derivatives (both as guarantor and beneficiary), ROA decreased by a nominal 0.065 when Total Derivatives increased by 1 . When BHC's that use credit derivatives are analyzed separately, ROA decreased significantly by 1.151 when the BHC sold credit derivatives, compared to increasing by 1.126 when the BHC sold credit derivatives (Table 2). This result supports both $\mathrm{H} 3$ and $\mathrm{H} 4$, and our findings is that there is a relationship between buying credit derivatives and selling credit derivatives, and Return on Asset, when BHC's engaged in this risk management strategy. Our finding with respect to our Secondary question no. 2 is that BHC's credit derivative use does affect performance.

Table 2: Regression Analysis ROA Against Independent Variables

\begin{tabular}{|c|c|c|c|c|c|c|}
\hline \multirow[t]{2}{*}{ Model } & & \multicolumn{2}{|c|}{$\begin{array}{c}\text { Unstandardized } \\
\text { Coefficients }\end{array}$} & \multirow{2}{*}{$\begin{array}{c}\begin{array}{c}\text { Standardized } \\
\text { Coefficients }\end{array} \\
\text { Beta } \\
\end{array}$} & \multirow[t]{2}{*}{$\mathbf{t}$} & \multirow[t]{2}{*}{ Sig. } \\
\hline & & B & Std. Error & & & \\
\hline \multirow[t]{7}{*}{1} & (Constant) & .010 & .001 & & 11.127 & .000 \\
\hline & $\mathrm{TL}$ & .006 & .001 & .228 & 4.303 & .000 \\
\hline & $\mathrm{NCO}$ & .026 & .005 & .265 & 5.294 & .000 \\
\hline & TD & .000 & .000 & -.065 & -.774 & .440 \\
\hline & CDGA & -.046 & .012 & -1.151 & -3.975 & .000 \\
\hline & TAG & .000 & .000 & .175 & 3.507 & .001 \\
\hline & CDBA & .041 & .010 & 1.126 & 4.101 & .000 \\
\hline
\end{tabular}

a Dependent Variable: ROA

Will buying credit derivatives lead to greater loan defaults? 
A T-test of two means was conducted, to analyze the Net Charge Off To Loans for BHC's that use credit derivatives, in comparison to those that do not. The mean NCO to Loans was 0.024226 for BHC's using credit derivatives, and 0.011261 for BHC's that did not use credit derivatives. With a p value of 0.051 (Table 3), we cannot reject the null hypothesis that there is no relationship between buying credit derivatives and BHC Net Charge Off's To Loans. We therefore reject H5 and our finding with respect to our Secondary question no. 3 is that BHC's credit derivative use does not encourage moral hazard. This therefore means that strong loan practices are still adhered to by BHC's that purchase credit derivatives as a risk management tool.

Table 3: T-Test - Net Charge Off To Loans BHC's that Use Credit Derivatives verses BHC's that Do Not Use Credit Derivatives

\begin{tabular}{|c|c|c|c|c|c|c|c|c|}
\hline \multicolumn{2}{|c|}{} & $\begin{array}{c}\text { Levene's Test } \\
\text { for Equality of } \\
\text { Variances }\end{array}$ & \multicolumn{2}{|c|}{ t-test for Equality of Means } \\
\cline { 2 - 9 } & F & Sig. & t & df & $\begin{array}{c}\text { Sig. } \\
\text { (2- } \\
\text { tailed) }\end{array}$ & $\begin{array}{c}\text { Mean } \\
\text { Difference }\end{array}$ & $\begin{array}{c}\text { Std. Error } \\
\text { Difference }\end{array}$ & $\begin{array}{c}\text { 95\% Confidence Interval } \\
\text { of the Difference }\end{array}$ \\
\hline NCO & $\begin{array}{c}\text { Equal } \\
\text { variances } \\
\text { assumed } \\
\text { Equal } \\
\text { variances } \\
\text { not } \\
\text { assumed }\end{array}$ \\
\end{tabular}

Our conclusions are that based on information presented in this study, the use of credit derivatives by BHC's while it increases risk, it also improves BHC performance. In support of MPT credit derivatives are a way of diversifying portfolio risk so as to achieve that balance of risk and return that the BHC is willing to bear (or that the shareholders are willing to take), in search of the efficient frontier

\section{REFERENCES}

1. $\quad$ Asher, J. (1998). Credit Derivatives: A Red-Hot Growth Area. ABA Banking Journal, 90, (8), 33-34.

2. $\quad$ BBA. (2002). Credit Derivatives Report 2001/2002. London: British Bankers' Association.

3. $\quad$ BBA. (2004). Credit Derivatives Report 2003/2004. London: British Bankers' Association.

4. Brandon, K. and Fernandez, F. (2005). Financial Innovation and Risk Management: An Introduction to Credit Derivatives. Journal of Applied Finance, 15, (1), 52-63.

5. Broll, U., Pausch, T., and Welzel, P. (2002). Credit Risk and Credit Derivatives in Banking. University of Augsburg Economics Discussion Paper No. 228

6. Broll, U., Schweimayer, G., and Welzel, P. (2004). Managing Credit Risk with Credit and Macro Derivatives. Schmalenbach Business Review, 56, (4), 360-378.

7. Charest, G. (1978). Split Information, Stock Returns And Market Efficiency - I. Journal of Financial Economics, 6, 265-296.

8. Copeland, T. E., Weston, J. F., and Shastri, K. (2005). Financial theory and Corporate policy (4th ed.). New York: Pearson Addison Wesley.

9. Das, S. R., Fong, G., and Geng, G. (2001). Impact of Correlated Default Risk on Credit Portfolios. The Journal of Fixed Income, 11, (3), 9-19.

10. Diamond, D. (1984). Financial Intermediation and Delegated Monitoring. Review of Economics Studies, 51, (3), 393-414.

11. Dong, H. (2005). The Effectiveness of Credit Derivatives on Bank Portfolio Management: An Empirical Analysis. (Doctoral dissertation, George Washington University - District of Columbia, 2005). 
12. Duffee, G. and Zhou, C. (2001). Credit Derivatives in Banking: Useful Tool for Managing Risk? Journal of Monetary Economics, 48, (1), 25-54.

13. Duffie, D. and Pan, J. (1997). An Overview of Value At Risk. Journal of Derivatives. 4, (3), 7-49.

14. Fama, E. F. (1985). What's Different about Banks? Journal of Monetary Economics, 15, (1), 29-39.

15. Herring, R. J. (1999). Credit Risk And Financial Instability. Oxford Review of Economic Policy, 15, (3), 6379.

16. Instefjord, N. (2005). Risk And Hedging: Do Credit Derivatives Increase Bank Risk. Journal of Banking \& Finance, 29, (2), 333-345.

17. Jackson, P., Maude, D., and Perruadin, W. (1997). Bank Capital And Value at Risk. Journal of Derivatives, 4, (3) 73-109.

18. Jacobson, T., Lindé, J., and Roszbach, K. (2006). Internal Rating Systems, Implied Credit Risk And The Consistency Of Banks' Risk Classification Policies. Journal of Banking and Finance, 30, (7), 1899-1931.

19. Lummer, S. L. and McConnel, J. J. (1989) Further Evidence On The Bank Lending Process And The Capital Market Response to Bank Loan Announcements. Journal of Financial Economics, 25, (1), 99-122.

20. Mester, L. J., Nakamura, L. I., and Renault, M. (2004). Transactions Accounts And Loan Monitoring. Economic Review - Federal Reserve Bank of Philadelphia Working Paper 04-20.

21. Morrison, A. (2005). Credit Derivatives, Disintermediation, And Investment Decisions. The Journal of Business, 78, (2), 621-647.

22. Neal, R. S. (1996). Credit Derivatives: New Financial Instruments For Controlling Risk. Economic Review Federal Reserve Bank of Kansas City, 81, (2), 15-27.

23. Park, S. (1998). Credit Risk. ABA Banking Journal 90, (8), 30-33.

24. Robicheaux, S. (2005). The Evolution Of Derivative Use By Community Banks From 1995-2003. Academy of Commercial Banking and Finance, 5, (1), 9-12.

25. Rose, P. S. and Hudgins S. C., (2005). Bank Management \& Financial Services. $\left(6^{\text {th }}\right.$ Ed.) New York: McGraw-Hill Companies, Inc. 